\title{
DICTOGLOSS IN IMPROVING LISTENING COMPREHENSION
}

\author{
Luh Ketut Sri Widhiasih \\ Universitas Mahasaraswati Denpasar \\ sriwidhiasih@gmail.com
}

\begin{abstract}
The objective of this classroom action research was to know whether or not listening comprehension of the Basic Listening class students of English Language Education Study Program, Faculty of Teacher Training, Mahasaraswati Denpasar University academic year 2016/2017 can be improved through dictogloss technique. The present research was carried out through dictogloss technique in two cycles; each cycle consisted of two sessions. The data were collected by administering the instruments to the subjects. The result of the post test in each cycle showed that there was significant improvement of the subjects' comprehension in listening. The subjects also gave positive responses toward the implementation of dictogloss technique in teaching and learning process. To sum up, the present classroom action research showed that listening comprehension of the Basic Listening class students of English Language Education Study Program, Faculty of Teacher Training, Mahasaraswati Denpasar University academic year 2016/2017 can be improved through dictogloss technique.
\end{abstract}

Keyword: improving, listening comprehension, dictogloss

\section{A. Introduction}

Listening is one of the English skills that is very important for the students' success in learning the language. Acquiring listening skill will improve their ability to identify and understand what others are saying or talking about. It means that having a lot of practices in listening will make it familiar and easy for students to understand the language. From listening, students will learn new words about how to pronounce, spell correctly and use them in a real life. Furthermore, it gives a good improvement to the other skills especially speaking skill since through listening learners can adopt the way how the native speakers speak.

Buck (2002:95) states that listening spends 45 percent of the time of communicating. It seems that listening takes larger portion than the other skills in communicating process. It is a preparative or the basic skill that helps foreign language learners to understand the sound of a language and its practical system. Richards (2008:3) states that listening as comprehension is the traditional way of thinking about nature of listening indeed, in most methodology manuals listening and listening comprehension are synonymous. This view of listening is based on assumption that the main function of listening is to facilitate understanding of spoken discourse; in this view, by listening, the understanding of spoken discourse in the second language learning can be facilitated.

According to Brown (2006:3), listening is a bit different from reading. For instance, students can skim a text 
quickly to get a good idea what it is about, but listeners cannot skim. The language comes rushing in at them. Listening must be done in real time; there is no second chance, unless, of course, the listener specifically asks for repetition. When students read cognates or the words that are similar in two languages, it will help them to understand. But while cognates may look alike on the page, their sounds may be quite different and they may be less useful while listening. Listening also involves understanding all sorts of reductions of sounds and blending of words.

Based on pre observation of students' ability on listening at Basic Listening class at English Language Education Study Program, Faculty of Teacher Training, Mahasaraswati Denpasar University, it could be seen that the students had less motivation to comprehend the spoken text and sometimes they felt lazy to follow the class because of the audio too quick to be heard. That condition made the students found difficulties in comprehending the spoken text. The students even could not catch any words or information from the spoken text. Sometimes, the students only jotted down the answer from the spoken text without developing the spoken text. They also failed at focusing themselves to listen the spoken text. They were easily panic when they got lost of any information. The panicness made them later on lost more information that made them failed in comprehending the spoken text.

The researcher believes that using an appropriate technique is the best way in improving the students' listening comprehension. Dictogloss is one of the listening techniques that can make the students well motivated in their learning process. Dictogloss can help the students in listening to obtain, process, construct, and provide information in spoken and written form. It can motivate and help the students to comprehend the text easily. However, it can motivate the student to work and interact each other.

The strengths of dictogloss technique are the students become active and focus in listening the spoken text. The students hear the text easily because the text read by the teacher and it is not too quick to be heard; besides, the students will comprehend the text easily as the teacher's pronunciation is easier to be heard than the native speaker. In addition, by applying this technique which the students should reconstruct the text, therefore, the students learn some new vocabularies. Thus, it makes the students' ability in mastering vocabularies would be improved too.

Based on the explanation above, the researcher was highly motivated to conduct this present research to improve listening comprehension by using dictogloss technique. Finally, in the end of the lesson, this technique is expected to improve listening comprehension of the Basic Listening class students of English Language Education Study Program, Faculty of Teacher Training, Mahasaraswati Denpasar University academic year 2016/2017.

Therefore, the research problem can be formulated as follows: can listening comprehension of the Basic Listening class students of English Language Education Study Program, Faculty of Teacher Training, Mahasaraswati Denpasar University 
academic year 2016/2017 be improved through dictogloss? From the research problem above, the objective of the study was to know whether or not listening comprehension of the Basic Listening class students of English Language Education Study Program, Faculty of Teacher Training, Mahasaraswati Denpasar University academic year 2016/2017 can be improved through dictogloss technique. This present study limited the research on improving listening comprehension of the Basic Listening class students of English Language Education Study Program, Faculty of Teacher Training, Mahasaraswati Denpasar University academic year 2016/2017 through dictogloss. Besides, in conducting the dictogloss, the researcher improved listening comprehension that was focused on identifying and finding the specific information in the spoken text in the form of descriptive text about place.

\section{B. Theoritical Review \\ Listening Comprehension}

Flowerdew and Miller (2005:51) state that listening is a short-lived activity and, unlike readers, listener cannot control the speed with which they process the next. Nor they can backtrack to make sure that they have understood correctly. For this reason, speakers often repeat or rephrase part of their message in order to facilitate comprehension that is used in language teaching to refer to a complex process that allows them in order to understand the spoken language.

Broughton et al. (2003:65) argue that it is not impossible to expect a student to produce a sound which does not exist in his mother tongue or a natural sentence using the stress, rhythms and intonation of a native speaker of the foreign language without first of all providing him with a model of the form he is to produce. It is not possible to produce satisfactorily what one has not heard. The logical first step, therefore, in attempting to achieve oral fluency or accuracy is to consider the learner's ability to listen. Meanwhile, Carter and Nunan (2001:1) explain that the term of listening is used in language teaching to refer a complex process that allows us to understand the spoken language. Listening is the most widely used language skill, is often used in conjunction with other skills of speaking, reading and writing. Listening is not only a skill area in language performance, but it is also critical means of acquiring a second language (L2).

Moreover, listening is the channel in which people process language in real time, employing pacing, units of encoding and pausing that are unique to spoken language. Meanwhile, Richards (2008:11) posts that successful listening can also be looked at in terms of the strategies the listener uses when listening. A focus on how to listen raises the issues of listening strategies. Strategies can be thought of as the ways in which a learner approaches and manages a task, and listeners can be taught effective ways of approaching and managing their listening. These activities seek to involve listeners actively in the process of listening.

According to the explanations above, the researcher can conclude that listening comprehension of the Basic Listening class students of English 
Language Education Study Program, Faculty of Teacher Training, Mahasaraswati Denpasar University academic year 2016/2017needed to be improved since there were several problems found during the observation and interview. An appropriate technique was needed in order to improve students' listening comprehension.

\section{Dictogloss}

In teaching and learning process, teacher can implement a variety of strategies and technique. The strategies and techniques have to be appropriate with the curriculum and students' mental development. It aims to motivate and stimulate students' interest in learning in order to achieve the standard competence. Especially in teaching listening, teacher can apply dictogloss technique in order to help the students easier in understanding the spoken text. It also can increase the students' interaction because the technique encourages students to work in group in order to re-create the given text.

According to Nunan (2008:28), dictogloss is a technique which encourage learner to utilize both bottomup and top-down listening strategies. Here, the teacher reads a passage at normal speed to learners who listen and write down as many words as they can identify. They then collaborate in small groups to reconstruct the text on the basis of the fragments which they have written down. The dictogloss technique provides a useful bridge between bottom-up and top-down listening. In the first instance, learners are primarily concerned with identifying individual element text (bottom-up strategy). However, during the small group discussions, some or all of the top-down strategy might be employed. Such as identifying the text type, making prediction, making interference about things not stated directly in the text, and identifying the topic of the text. Dictogloss exploit the principle that two heads are better than one. Students are able to pool their resources, and even low-level learners are able, through collaborative action, to 'outperform their competence'.

Moreover, Herrell and Jordan (2008:246) state that dictogloss is a strategy developed by Wajnryb (1990) for use with high school students, but it can be adapted for use with all ages. It is a classroom dictation activity when learners listen to passage, note down key words and then work together to create a reconstructed versions of the text. Dictogloss technique is very useful in listening and learning about their ability to monitor the students both in classroom and outside the classroom. Learners listen to a passage, note down a key words or phrase and then encourage comparison. Dictogloss activities are useful way of presenting new factual information to the students, and encourage them to listen to key points and understanding the listening. The steps in teaching dictogloss lesson as follows:

1. Selecting an appropriate a piece of text Teacher selects a content-related text and reads it aloud at a normal speaking pace. At first, teacher instructs the students to "Just listen carefully."

2. Reread the text orally 
Teacher reads the text twice more. The students are now instructed, "Jot down the key words and phrases."

3. Pair to re-create the text

Teacher asks students work in pairs to re-create as much of the text as possible using the notes taken by each of the partners to write the text as closely as possible to the original text as read by the teacher.

4. Work in groups of four

Teacher asks two pairs of students meet together and pool their recreations of the text to reconstruct it more completely. Teacher asks the group of four works together to write down as much of the text as possible. Their aim is to re-create it as closely as possible to the original text.

5. Read the re-created text

Teacher asks one member for each group to read the group's re-creation of the text and ask the other groups to see how closely it matches their versions. Teacher displays the groups' re-created text, compares, discusses them, noting the sections in the text that are difficult to re-create.

According to Larsen-Freeman and Anderson (2011: 185), students listen twice to a short talk or a reading on appropriate content. The first time through, students listen for the main idea, and then the second time they listen for details. Next, students write down what they have remembered from the talk or reading. Some teachers have their students take note while listening. The students then use their note to reformulate what has been read. Students get practice in note-taking in this way. Next, they work with a partner or in a small group to construct together the best version what they have heard. What they write is shared with the whole class for a peer-editing session. Through these processes, students become familiar with the organization of a variety of texts within a content area.

In conclusion, dictogloss is one of the techniques which encourage learner to utilize both bottom-up and top-down listening strategy; moreover, dictogloss is used for high school students and it can be adapted for all ages. Through the dictogloss processes, the students become familiar with the organization of a variety of texts within a content area.

\section{Research Method}

The subjects of the present study were the students of the Basic Listening class of English Language Education Study Program, Faculty of Teacher Training, Mahasaraswati Denpasar University and it consisted of 35 students. The type of investigation used in this research is classroom action research (CAR). In this classroom action study, the teaching and learning processes divided into some cycles where each cycle consists of two sessions. Each session consisted of four interconnected activities namely: Planning, Action, Observation, and Reflection.

The data that were collected by the researcher were used to know whether the students' listening comprehension was improved after applying dictogloss. In collecting the data, there were several instruments used such as test (pre-test, post-test) and questionnaire.In gathering quantitative data, test is very important. There were two kinds of tests which were used for 
the present study. They were pre-test and post-test. Pre-test was administered to measure the students' knowledge. The purpose of pre-test was to find out the real problem which is faced by the students. In addition, it was used to know the students' pre-existing listening comprehension ability. Post test was used to know how far the improvement of the subjects listening comprehension after the teaching technique would apply.Herrell and Jordan (2008:247) state that to assess the students listening skills we can make copies of the final recreated text and asking each student to highlight the parts they contributed or remembered. In order to do this, the teacher has to determine the main ideas in the text. If there were 10 main ideas in the text and the student remember 8 of them, the student graphs it as 80 percent.

Questionnaire was merely aimed at covering the responses of the subjects when the technique was implemented which are not covered by tests. The questionnaire in this study in a form of Likert rating scale which was arrange from five (5) to one (1) alternative choices. Furthermore, the questionnaire was written in Bahasa. Since questionnaire was implemented, it required the subjects to select one of five choices: strongly agree (Sangat Setuju/SS), agree (Setuju/S), undecided (Ragu-Ragu/RR), disagree (Tidak Setuju/TS), strongly disagree (Sangat Tidak Setuju/STS) based on 10 following statements that related to the application of dictogloss. The questionnaire was given in the second cycle after the technique implemented and after all the subjects had finished writing the second post-test.
There were two kinds of instrument that was used by the researcher to collect the data of the classroom action research; they were test (pre-test and post-test) and questionnaire. The pre-test was done before the teaching and learning process was begun. The aim was to know about the pre-existing ability of the students' listening comprehension. Then, it was post-test. The post test was done at the end of every cycle or after doing the teaching learning process. The purpose was to know the students' improvement from the beginning of the teaching and learning process. The questionnaire was chosen by the researcher to know about the responses of subjects about the application of dictogloss.

The data from the pre-test and posttest was calculated in order to find the answer whether the objective of the study could be reached through the implementation of dictogloss. Then they will be described using the formula:

$$
\mathrm{M}=\frac{\sum \mathrm{x}}{\mathrm{N}}
$$

Note:

M : the mean score / average score of all students

$\Sigma \mathrm{x} \quad$ : the sum of the total

$\mathrm{N}$ : the total number of subjects under the study

Moreover, the data was gained through questionnaire aimed at knowing the response of the subjects towards the application of dictogloss as well formulating by the following percentage formula:

$\begin{aligned} & \text { Percentage } \\ & \frac{\text { Total responses of an item }}{\text { Total responses of all items }} \times 100 \%\end{aligned}=$

Based on the curriculum that used in English Language Education 
Study Program, Faculty of Teacher Training, Mahasaraswati Denpasar, the minimum standard score of the English students' mastery is 70 . Therefore, this classroom action research was regarded as successful when $80 \%$ of the subjects under the study could achieve the minimum score 70 . It could be said that at least 28 of 35 students of Basic Listening class in English Language Education Study Program, Faculty of Teacher Training, Mahasaraswati Denpasar should achieve the minimum standard score to stop the research.

\section{Findings}

There were three sets of data in this study that were tabulated as follows:

Table 4.1

The Tabulation of Data Showing the Subjects' Progressing Scores in Listening Comprehension

\begin{tabular}{|l|l|l|l|}
\hline \multirow{3}{*}{ Subjects } & Pre-Cycle & Cycle I & Cycle II \\
\cline { 2 - 4 } & Pre-Test & $\begin{array}{l}\text { Post-Test } \\
\text { I }\end{array}$ & $\begin{array}{l}\text { Post- } \\
\text { test II }\end{array}$ \\
\hline 1 & 50 & 60 & 70 \\
\hline 2 & 50 & 60 & 80 \\
\hline 3 & 60 & 70 & 70 \\
\hline 4 & 50 & 50 & 70 \\
\hline 5 & 50 & 60 & 80 \\
\hline 6 & 50 & 60 & 80 \\
\hline 7 & 20 & 60 & 70 \\
\hline 8 & 50 & 60 & 80 \\
\hline 9 & 40 & 50 & 70 \\
\hline 10 & 50 & 60 & 80 \\
\hline 11 & 40 & 60 & 70 \\
\hline 12 & 60 & 60 & 60 \\
\hline 13 & 60 & 70 & 70 \\
\hline 14 & 50 & 70 & 80 \\
\hline 15 & 60 & 60 & 80 \\
\hline 16 & 60 & 60 & 70 \\
\hline 17 & 50 & 60 & 70 \\
\hline 18 & 60 & 60 & 80 \\
\hline 19 & 50 & 60 & 80 \\
\hline 20 & 50 & 60 & 60 \\
\hline
\end{tabular}




\begin{tabular}{|c|c|c|c|c|c|}
\hline 12 & 10 & 32 & - & - & - \\
\hline 13 & 15 & 28 & - & - & - \\
\hline 14 & 35 & 12 & - & - & - \\
\hline 15 & 20 & 20 & 3 & - & - \\
\hline 16 & 25 & 12 & 6 & - & - \\
\hline 17 & 15 & 16 & 9 & - & - \\
\hline 18 & 30 & 8 & 6 & - & - \\
\hline 19 & 10 & 16 & 12 & - & - \\
\hline 20 & 20 & 8 & 12 & - & - \\
\hline 21 & 30 & 4 & 9 & - & - \\
\hline 22 & 10 & 24 & 6 & - & - \\
\hline 23 & 40 & 8 & - & - & - \\
\hline 24 & 10 & 24 & 6 & - & - \\
\hline 25 & 35 & 12 & - & - & - \\
\hline 26 & 10 & 28 & 3 & - & - \\
\hline 27 & 40 & 4 & 3 & - & - \\
\hline 28 & 35 & 4 & 6 & - & - \\
\hline 29 & 30 & 12 & 3 & - & - \\
\hline 30 & 20 & 12 & 9 & - & - \\
\hline 31 & 10 & 28 & 3 & - & - \\
\hline 32 & 25 & 8 & 9 & - & - \\
\hline 33 & 25 & 20 & - & - & - \\
\hline 34 & 5 & 4 & 24 & - & - \\
\hline 35 & 15 & 24 & - & 2 & - \\
\hline Total & 750 & 520 & 207 & 2 & 0 \\
\hline $\begin{array}{l}\text { Precenta } \\
\text { ge }\end{array}$ & $\begin{array}{l}50.71 \\
\%\end{array}$ & $\begin{array}{l}35.16 \\
\%\end{array}$ & $\begin{array}{l}14.00 \\
\%\end{array}$ & $\begin{array}{l}0.14 \\
\%\end{array}$ & $\begin{array}{l}0 \\
\%\end{array}$ \\
\hline \multicolumn{6}{|c|}{ Grand Total = 1479} \\
\hline
\end{tabular}

Moreover, in order to give clear presentation of the data, the findings of the present classroom action research showed the rising comparative of the mean scores of pre-test, post-test 1 in cycle I and post-test 2 in cycle II could be presented in the form of graphs as follows:

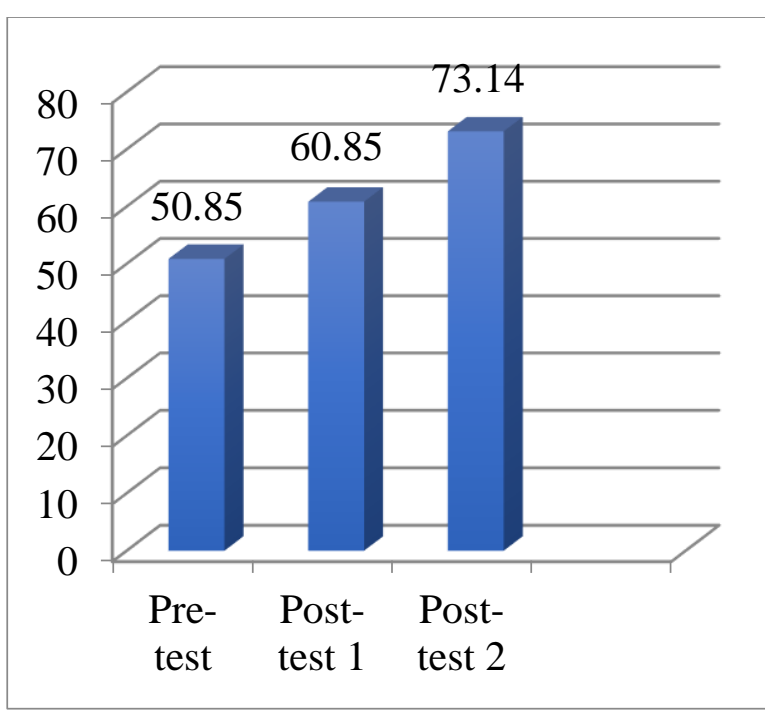

Graph 4.3 Depicting the Subjects' Progressing Achievement of Listening in Pre-test, Post-test 1 and Post-test 2

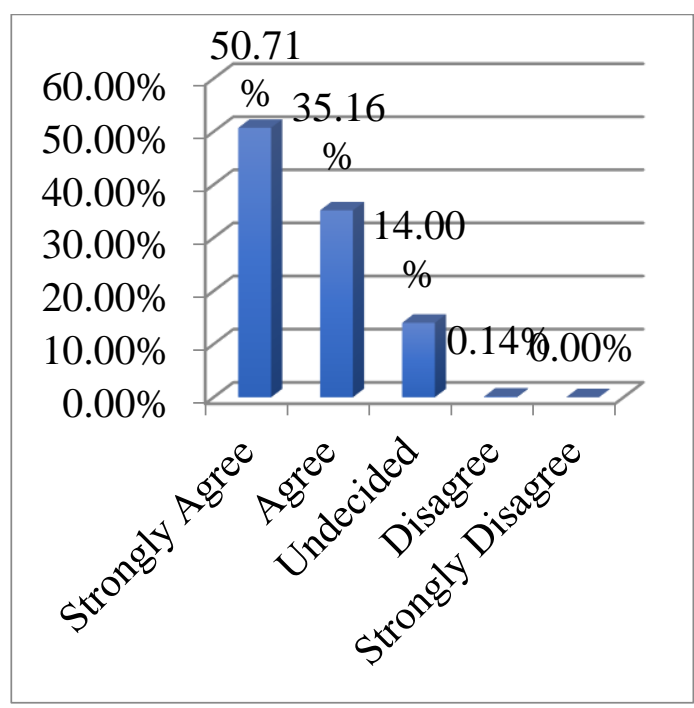

Graph 4.4 Depicting the Subjects' Responses after the Application of Dictogloss in Teaching Listening

\section{E. Discussion}

This study was used classroom action research. It was intended to improve listening comprehension of the Basic Listening class students of English Language Education Study Program, Faculty of Teacher Training, Mahasaraswati Denpasar University 
academic year 2016/2017. This research was started by conducting a pre-cycle at the very beginning. Furthermore, there were two cycles that were done in the present study; they were cycle I and cycle II. Each cycle were used to collect the data to know the improvement of the subjects after implementing dictogloss technique.

In pre-cycle, the researcher noticed that the subjects still had several problems in listening comprehension. The result of the data analysis also showed low listening comprehension. The mean score of the pre-test was 50.85 . There was none of the subjects pass the minimum passing grade. The researcher found that the subjects' weakness was in listening especially in comprehending the spoken text. On the other hand, motivation and focus become problem when the research was conducted at the pre-cycle. The researcher had to make an effective planning for the research to improve the subjects' listening comprehension.

In cycle I, the researcher taught the subjects by using dictogloss. Based on the data analysis after administering post-test in the end of cycle I, dictogloss technique helped the subjects to improve their listening comprehension. The data showed the subjects' improvement in post-test was 60.85 . there were 6 of 35 subjects who passed the minimum passing grade. In the first session, there were only few subjects who were active in asking the question and they still talked with their friends. However, in the second session, the subjects the subjects were more active than the first session. In addition, there was improvement from the subjects' listening improvement. Moreover, the implementation of 66 dictogloss technique showed the improvement of the subjects' in listening comprehension during teaching and learning process. The success indicator was not yet achieved. The subjects still had difficulties in comprehending the spoken text. Therefore, to get better result, the researcher revised the planning for the next cycle. Then, the researcher conducted cycle II.

In cycle II, the researcher made some revisions in teaching and learning process. The researcher reconstructed the planning to achieve the highest result in action. The result of cycle II with some revisions in the lesson plan also showed that the subjects' listening comprehension could be improved through dictogloss technique. The mean score also showed an improvement from the subject. In the third and fourth session, the subjects were more active in asking questions and also they were enthusiastic during teaching and learning process. The mean score of the subjects improved if it was compared with the pre-test and post-test 1 of the cycle I. Furthermore, in this cycle there was 31 subjects could passed the minimum passing grade and the present classroom action research could be ended.

In addition, the data of the questionnaire stated that the most of the subjects gave the positive responses about the implementation of dictogloss technique in improving the subjects' listening comprehension. The data showed that $50.71 \%$ of the subjects present study strongly agree to the improvement of listening comprehension of the subjects present study through dictogloss; $35.16 \%$ of the subjects present study agreed to the improvement of 
listening comprehension of the subjects present study through dictogloss; $14.00 \%$ of the subjects present study undecided agree to the improvement of listening comprehension of the subjects present study through dictogloss; $0.14 \%$ of the subjects present study disagree agree to the improvement of listening comprehension of the subjects present study through dictogloss; and $0.00 \%$ of the subjects present study strongly disagree to the improvement of listening comprehension of the subjects present study through dictogloss. The questionnaire was really helpful for them because it motivated them to develop their ideas that appeared in their mind and it helped them to create confident and critical thinking because they compared their taught with their friends.

Based on the findings of the present classroom action research it showed that the subjects' listening comprehension improved. Moreover, dictogloss technique was effective to be implemented in teaching listening especially comprehend the spoken text. Therefore, it can be concluded that dictogloss technique could improve listening comprehension of the Basic Listening class students of English Language Education Study Program, Faculty of Teacher Training, Mahasaraswati Denpasar University academic year 2016/2017.

\section{F. Conclusion}

The objective of the study of conducting this study was to improve listening comprehension of the Basic Listening class students of English Language Education Study Program, Faculty of Teacher Training,
Mahasaraswati Denpasar University academic year 2016/2017 by implementing dictogloss technique. Based on the result of pre-test in pre-cycle and post-test in cycle I and II, there was significant improvement of the subjects' listening comprehension. It was indicated by the total of the subjects who could obtain the minimum passing grade that increased significantly. This increasing mean score showed that the subjects' listening comprehension could be improved by implementing dictogloss. In addition, the result of questionnaire showed most of the subjects gave positive responses of the technique used. Therefore, it can be conclude that listening comprehension of the Basic Listening class students of English Language Education Study Program, Faculty of Teacher Training, Mahasaraswati Denpasar University academic year 2016/2017 could be improved through dictogloss technique.

\section{G. Suggestion}

In the present classroom action research, the researcher gave some suggestions which could be used as consideration for further and better teaching and learning process at Basic Listening class of English Language Education Study Program, Faculty of Teacher Training, Mahasaraswati Denpasar University. The researcher would like to propose some suggestions for the lecturer of Basic Listening class, the Basic Listening class students and the other researchers.

The lecturer of Basic Listening class are suggested to use dictogloss as an alternative technique in teaching listening since it can build up the students' interest 
and motivation in learning listening comprehension. The technique also made the subjects enjoy the learning activity. Moreover, the researcher also recommends the lecturer of Basic Listening class to combine this technique with another strategy, which can greatly increase the motivation of the students.

The Basic Listening class students are suggested to increase their listening comprehension because they will learn something from listen and comprehend the spoken information. They should listen more everything about spoken information in English in order to practice their listening comprehension. Moreover, the students will comprehend the spoken information in English easily when they listen to it very often. They should motivate and encourage themselves to practice and listen more by using dictogloss as the technique could help to build up their motivation and interest.

Moreover, the other researchers are suggested to apply dictogloss technique in teaching listening in different level of the students. This technique improved students' listening comprehension by giving them more opportunity to develop the general information and specific information based on their comprehension. On the other hand, the result of this study can be used as a reference to conduct further researchers that was related to the implementation of dictogloss technique.

\section{REFERENCES}

Brown, H. (2004). Language Assessment:

Principles and Classroom

Practices. New York: San

Fransisco State

University.Broughton , G.,

Brumfit, C., Flavell, R., Hill,

P. and Pincas, A. (2003).

Teaching English as A Foreign

Language. New York:

Routledge

Buck, G. (2002). Assessing Listening (second published). Cambrigde: Cambridge University Press

Carter, R. and Nunan, D. (2001). The Cambridge Guide to Teaching English to Speakers of Other Language. Cambridge: Cambridge University Press.

Flowerdew, J. and Miller, L. (2005).

Second Language Listening Theory and Practice. New York: Cambridge University Press.

Herrell, A. and Jordan, M. (2008). Fifty Strategies for Teaching English Language Learners. Ohio: Prentice Hall.

Nunan, D. (2004). Language Teaching Methodology. Sydney:

Maquarie University.

Richards, J.C. (2008). Teaching Listening and Speaking from Theory to Practice. New York: Cambridge University Press. 